\title{
卜
}

\section{Piezoelctric and Elastic Constants of Bone}

\author{
by \\ Hideatsu MaEdA, Keishiro TsUdA, and Eiichi FuKadA* \\ (Research Institute for Polymers and Textiles, Sawatari, Kanagawa-ku, Yokohama, 221 \\ and ${ }^{*}$ The Institute of Physical and Chemical Research, Wako, Saitama 351)
}

The piezoelectric and elastic constants of bone were determined at $10 \mathrm{~Hz}$ in the range of temperature from -150 to $150^{\circ} \mathrm{C}$. The piezoelectric constant of dry bone was nearly independent of temperature. The piezoelectric constant of $7.4 \%$ hydrated bone was larger than that of dry bone at temperatures below $0^{\circ} \mathrm{C}$, but smaller at temperatures above $0^{\circ} \mathrm{C}$. Similarly, the elastic constant of hydrated bone was larger than that of dry bone at below $-30^{\circ} \mathrm{C}$, and smaller at above $-30^{\circ} \mathrm{C}$. A theoretical estimate of the piezoelectric constant of bone was made by using a parallel combination model of collagen fibers and hydroxyapatite crystals, which was in agreement with the observed value.

\section{骨の圧電性と粘 弾 性}

\author{
前田＼cjkstart秀篤・津田圭四郎* ・深田 栄一**
}

（原稿受理：1976年12月 4 日）

\section{1. 緒言}

近年, 骨の構造と物性に関する研究が盛んになってきている。 一つは材料力学の分野から, もろ一つは医学的な分野からである. 前者はやわらかい有機物の瀻維である一軸配向したコラーゲン繊 維と，その回りにあるかたい無機物であるハイドロオキシアパタ イトからなる物質が外部応力に刘して，どのようなレスポンスを するかを知り，材料面での有意義な知見を得ようとするものであ る. 一方, 後者の中には電気的刺激や, 外部応力が骨の生長とど のように関連しているかを知ることを目的とする立場がある.

骨の物性に関する研究の中で弾性率に関する実験が最も盛んで ある，弾性率の異方性を調べたもの，ある一定温度に打ける弾性 率の周波数と水和の依存性を調べたもの，コラーゲン繊維と無機 物の複合体の立場から弾性率を論じたもの等がある。骨の压電率 の研究は, 最近非常に注目され始め, その異方性を調べたものや, 温度依存性を調べたもの, またある一定温度に扔ける周波数依存 や水和の効果を調べたもの等がある. しかし現在のところ, 粘弾 性の低温に批ける水和の影響, 压電率の水和効果等, 十分に調心 られているとは言えない，このようなことを考慮に入れて，我々 は牛の骨の圧電率, 弾性率の温度と, 吸湿量依存性を調べた。

* 繊維高分子材料研究所 横浜市神奈川区沢渡 4-1

** 理化学研究所 埼玉県和光市広沢 $2-1$

\section{2. 試料および実験方法}

牛の骨をアルコールで10日間脱水した後，乾燥させる，骨を便宜 的に円筒状の形をしているとして，その長軸方向と平行な矩形の 板を切り出し，これをもとにして目的に応じた試料を作った，圧 電用の試料は, その長辺の方向が骨の長軸（繊維軸）と $45^{\circ}$ をな すようにし， $2.0 \times 0.7 \times 0.04 \mathrm{~cm}^{3}$ にした。粘弾性用の試料は長辺 が繊維軸方向のものと，それに直交するものが作られ，2.2×0.12 $\times 0.03 \mathrm{~cm}^{3}$ の大きさにした。実験は圧電率, 弾性率ともに $10 \mathrm{~Hz}$ の応力のもとに, $-150 \sim 150^{\circ} \mathrm{C}$ の間で行った。 また，実験装置 は既に報告されている1)ので省略する.

\section{3. 結果}

我々の測定した压電率は， $d_{14}$ の複素圧電率 $\left(d_{14}=d^{\prime}-i d^{\prime \prime}\right)$ で ある。これは先に述べた試料の長辺方向（緘維軸と $45^{\circ}$ の角度を なしている）に $10 \mathrm{~Hz}$ の応力を加えた時, 試料面に垂直な方向の 分極量を測定しているからである. Fig. 1, 2 亿吸湿量（重量パー セント) を変えた, 圧電率の $d^{\prime}, d^{\prime \prime}$ の温度依存性を示す。結果を 要約すると,

a 、乾燥状態では温度依存性はない。

$\mathrm{b}$. 水和の增加とともに $0^{\circ} \mathrm{C}$ 付近を境にして，それょり低温側 では圧電率の実数部分 $d^{\prime}$ は, 乾燥状態に比べて增大し, 


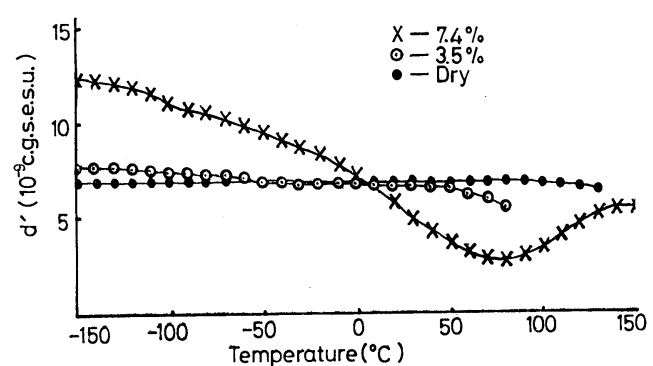

Fig. 1. Temperature dependence of the real part, $d^{\prime}$, of the piezoelectric constant, $d=d^{\prime}-i d^{\prime \prime}$, for bone with different hydration.

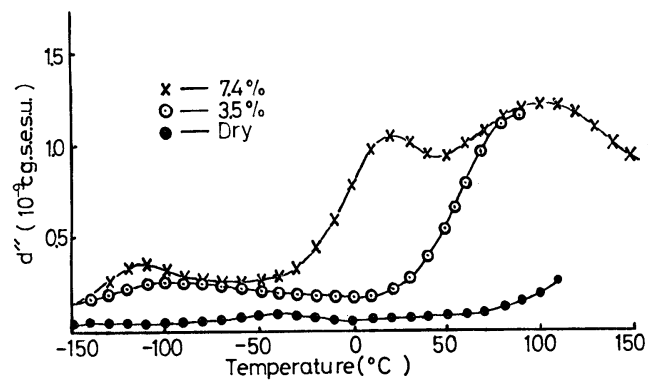

Fig. 2. Temperature dependence of the imaginary part, $d^{\prime \prime}$, of the piezoelectric constant, $d=d^{\prime}-i d^{\prime \prime}$, for bone with different hydration.

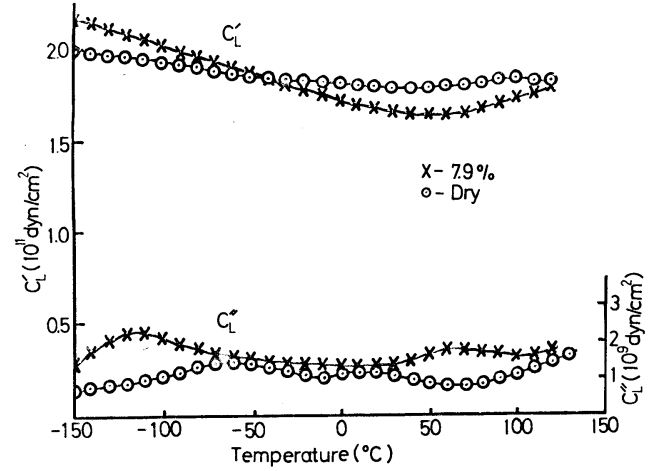

Fig. 3. Temperature dependence of the elastic constant, $c_{L}=c^{\prime}{ }_{L}+i c^{\prime \prime}{ }_{L}$, for hydrated and dry bone.

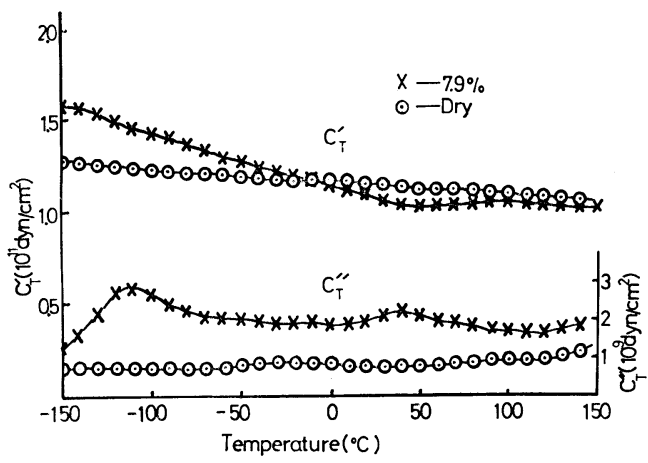

Fig. 4. Temprature dependence of the elastic constant, $c_{T}=c^{\prime}{ }_{T}+i c^{\prime \prime}{ }_{T}$, for hydrated and dry bone.
高温側では減少する.

c . $d^{\prime \prime}$ のピークは $-120^{\circ} \mathrm{C}, 20^{\circ} \mathrm{C}, 100^{\circ} \mathrm{C}$ 付近に三つ現れてい る. $-120^{\circ} \mathrm{C}$ と $20^{\circ} \mathrm{C}$ の゚ークは水和とともに低温側にずれ, そのピークの高さは水和とともに増大し, 幅は狭くなる。

次に Fig. 3, 4 飞絨維軸方向の弾性率 $c_{L}=c_{L}{ }^{\prime}+i c_{L}{ }^{\prime \prime}$ と, 繊維軸 に $90^{\circ}$ 方向の弾性率 $c_{T}=c_{T}{ }^{\prime}+i c_{T}{ }^{\prime \prime}$ の温度と吸湿量变化を示す. 結果を要約すると,

a . 弾性率の実数部は $-50 \sim-30^{\circ} \mathrm{C}$ 付近を境にして, 低温 側 では水和している方が弾性率が高く, 高温側では逆転する.

b . 繊維軸方向の弾性率 $c_{L}{ }^{\prime}$ は, 垂直方向の弾性率 $c_{T}{ }^{\prime}$ の約 1.5 倍である。

c . $-120^{\circ} \mathrm{C}$ 付近に損失ピークが現れる。水和の増大とともに 低温側にずれ，その高さは水和量の增大とともに高くなり， 幅は狭くなる。

\section{4. 考察}

骨を簡単にモデル化して压電摔を定式化し，更に実験結果を整 理し，検討する，骨を構成している要素をコラーゲン縬維とハイ ドロオキシアパタイトに限ることにする，また，結晶の対称性か らコラーダン分子は圧電性を示し， ハイドロオキシアパタイトは 压電性を示さないことがわかっている，更にこの二つの成分が Fig. 5 のよ5に応力 $T$ の方向に刘して並列で, 電極面に垂直な方 向に対しては直列になっている二層張り合わせモデルを用いるこ とにする，骨の圧電率を $d_{b}$ とすると（一般压電率は $d$ で示さ れる).

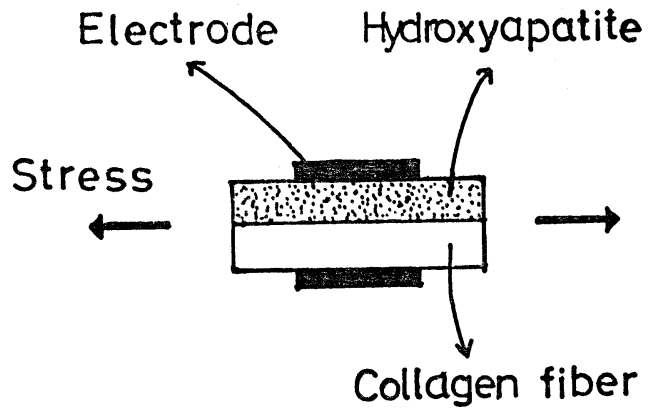

Fig. 5. A simplified model of bone. A two-layer structure is assumed: Hydroxyapatite crystals are embedded between oriented collagen fibers. The stress is given in the direction of orientation of collagen fibers and the polarization is observed in the direction perpendicular to the layers.

$$
d_{b} \equiv \frac{P_{b}}{T_{b}}=\phi_{c} \cdot d_{c} \cdot \frac{\varepsilon_{b}}{\varepsilon_{c}} \cdot \frac{c_{c}}{c_{b}}
$$

ここで, $P$ は分極量, $T$ は応力, $\phi$ は体積分率, $\varepsilon$ は誘電率, $c$ は弾性率を示している。 また，添字 $b, c$ はそれぞれ骨，コラーゲ ンを意味している。

式(1)を用いて実験結果を考察する。乾燥状態では $\varepsilon_{b}, c_{b}$ の温度 変化はあまりない2)(Fig. 3, 4)。 また $d_{c}, \varepsilon_{c}, c_{c}$ の温度変化もほ之 んどないことが既にわかっている3). 式(1)を見ればわかるように, このことは乾燥状態では $d_{b}$ の温度変化が十分小さいことを示唆 しているが，実際，骨の压電率の測定からわかるように，乾燥状 態では $d_{b}$ は温度変化しない，一方，水和した骨の压電率は室温 
以下では乾燥状態より大きいが，室温以上ではもしろ小さくなっ ている. 水和したコラーゲンは, 結晶化度が増大するといら X線 回折からの事実があるので, 式(1)の $\phi_{c} \cdot d_{c}$ の増大が $d_{b}$ を増大さ せる原因になっているのではないかと思われる，また，温度の上 升とともに圧電率の減少する主な原因は吸着した水分子の動きや 寸さの増加に伴い, 式(1)の $\varepsilon_{b} / \varepsilon_{c}$ が減少するためであると思われ る.このことはコラーゲンの直流電気伝導度がハイドロオキシア パタイトよりる大きいといらことを意味している，それは両者の 水和の程度の差などが原因になっているのかもしれない。

更に，式(1)を用いて $-150^{\circ} \mathrm{C}$ に扔けるd

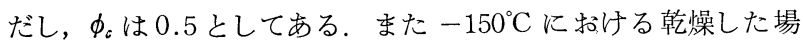
合の骨の弾性率は $1.3 \times 10^{11} \mathrm{dyn} / \mathrm{cm}^{2}$, 誘電率は 8.2 , 同様にコラ
ーゲンの圧電率は $6.0 \times 10^{-8}$, 弾性率は $3.0 \times 10^{10} \mathrm{dyn} / \mathrm{cm}^{2}$, 誘電 率は 4.5 である。これらの值を用いると, 骨の乾燥状態の圧電率 $d_{b}$ は式(1)から $8.5 \times 10^{-9}$ と予想される。 これは実測值 $6.8 \times 10^{-9}$ よりやや高いが, 式(1)自体が近似式なので, よい一致と思われる.

\section{文}

献

1) Furukawa, T., and E. Fukada, Rept. Progr. Polym. Phys. Japan, 18, 359 (1957).

2) Maeda, H., K. Tsuda, and E. Fukada, Japan. J. Appl. Phys., 15, 2333 (1976).

3) Fukada, E., H. Ueda, and R. Rinaldi, Biophys. J., 16, 911 (1976). 